\title{
Keefektifan Model Pembelajaran Bamboo Dancing dan Jigsaw Ditinjau Dari Hsail Belajar Matematika Siswa Kelas 4 SD
}

\author{
Fitria Nur Fiyany ${ }^{1}$, Mawardi $^{2}$, Suhandi Astuti ${ }^{3}$ \\ ${ }^{1}$ Pendidikan Guru Sekolah Dasar, Universitas Kristen Satya Wacana \\ ${ }^{1}$ fitrianurfiyany96@gmail.com, ${ }^{2}$ mawardi@staff.uksw.edu, ${ }^{3}$ suhandi.astuti70@gmail.com
}

\begin{abstract}
INFO ARTIKEL
Riwayat Artikel:

Diterima: 08-03-2018

Disetujui: 23-03-2018

\section{Kata Kunci:}

Bamboo Dancing

Jigsaw

Hasil Belajar

Matematika

ABSTRAK

Abstrak: Tujuan penelitian ini untuk mengetahui perbedaan yang signifikan antara model pembelajaran Bamboo Dancing dan Jigsaw ditinjau dari hasil belajar Matematika siswa kelas 4 SD Gugus Diponegoro Kota Salatiga. Jenis penelitian yang dilakukan adalah jenis penelitian kuasi eksperimen (quasi research).. Hasil penelitian menggunakan Uij T pada varian model pembelajaran, diperoleh T hitung sebesar 2,187 dan $\mathrm{T}$ tabel yaitu 1,664 dan taraf signifikansi sebesar 0,0155. Oleh karena nilai probabilitas 0,0155 lebih kecil dari 0,05 maka $\mathrm{H}_{0}$ ditolak dan diterima $\mathrm{H}_{\mathrm{a}}$, artinya hasil belajar Matematika dalam penerapan model pembelajaran Jigsaw lebih unggul daripada model pembelajaran Bamboo Dancing di SD Gugus Diponegoro Salatiga.

Abstract: The purpose of this study was to investigate any significant differences between Bamboo Dancing and Jigsaw learning method types reviewed from the fourth graders of SD Gugus Diponegoro Salatiga City's learning outcomes in mathematic. The technique used in the study was quasi research. The findings of the study through applying T-Test toward the learning method types being investigated resulted in $T_{\text {count }}$ is 2,187 and $T_{\text {tabel }}$ is 1,664 and 0.0155 or $<0.05$ significant rate. It indicated that the result of the Mathematic that use of Jigsaw learning type was more eminent than the Bamboo Dancing.
\end{abstract}

\section{A. LATAR BELAKANG}

Penanaman pemahaman siswa terhadap suatu konsep pembelajaran matematika dapat terpenuhi apabila guru mampu menumbuhkan suatu lingkungan belajar yang sesuai dengan karakteristik siswa. Menurut Sudijono (2012: 32) hasil belajar merupakan sebuah tindakan evaluasi yang dapat mengungkap aspek proses berpikir (cognitive domain) juga dapat mengungkap aspek nilai atau sikap (affective domain) dan aspek keterampilan (psychomotor domain) yang melekat pada diri setiap individu peserta didik. Artinya melalui hasil belajar, pencapaian siswa setelah melalui pembelajaran dapat diketahui.

Keberhasilan belajar tidak lepas dari beberapa faktor yang mendukungnya. Faktor-faktor belajar dapat berasal dari mana saja bisa dari siswa itu sendiri ataupun bisa juga dari lingkungan sekitar. Guru merupakan salah satu faktor penunjang dalam keberhasilan suatu pembelajaran. Tugas guru yaitu melaksanakan proses pembelajaran, menilai hasil pembelajaran dan juga melakukan pembimbingan kepada siswa (Suhandi Astuti, 2016: 119). Guru harus mampu menciptakan suasana pembelajaran yang mampu meningkatkan motivasi belajar siswa sehingga akan meningkatkan hasil belajar di akhir pembelajaran siswa. salah satu faktor yang mampu mempengaruhi hasil belajar seorang siswa yaitu penggunaan model pembelajaran pada suatu materi pembelajaran. . Penggunaan model pada suatu materi pembelajaran sangat penting karena karakteristik setiap materi pembelajaran berbeda. Pemilihan model pembelajaran harus sesuai dengan karakteristik materi pembelajaran dan juga karakter siswa.

Menurut Mawardi (2018: 29) model pembelajaran merupakan suatu kerangka konseptual yang digunakan untuk mencapai tujuan/kompetensi, dan sebagai pedoman dalam suatu proses pembelajaran karena berisi langkah/sintak pembelajaran yang sistematis. Penggunaan model pembelajaran kooperatif salah satu hal yang dapat menunjang suatu proses pembelajaran terutama pada mata pelajaran matematika. Dengan 
menggunakan suatu model pembelajaran akan menimbulkan rasa keingintahuan yang tinggi sehingga siswa akan mengikuti kegiatan pembelajaran secara aktif.

Penggunaan model kooperatif mampu menjadikan siswa untuk mencari pengetahuan sendiri dari berbagai sumber belajar di sekitarnya (Rismaerista Rini \& Mawardi, 2015: 103-113). Pembelajaran kooperatif adalah model pembelajaran yang sering digunakan dalam pembelajaran matematika, karena model pembelajaran kooperatif memiliki hakikat dan tujuan dengan pembelajaran matematika.

Beberapa model pembelajaran kooperatif yang dapat dilakukan oleh guru agar peserta didik tidak malas untuk berpikir, aktif dalam pembelajaran dan tidak hanya mendengarkan penjelasan guru (pembelajaran yang pasif). Menurut Agus Suprijono (2012) model pembelajaran kooperatif terdiri dari beberapa tipe, yaitu Student Teams Achievement Divisions (STAD), Jigsaw, Group Investigation, Teams Games Turnaments (TGT), Team Assisted Individualization (TAI), Snowball Throwing, Numbered Head Together (NHT), Cooperative Integrated Reading and Composition (CIRC), Make a Macth, Think Pair Share (TPS), Course Review Horay (CRH), Talking Stick dan sebagainya.

Diantara model-model pembelajarna kooperatif Model pembelajaran Bamboo Dancing dan Jigsaw merupakan tipe model pembelajaran kooperatif, kedua model pembelajaran ini relevan terhadap pembelajaran matematika. Dalam pembelajaran ini siswa akan belajar secara berkelompok secara heterogen. Guru akan berperan sebagai seorang fasilitator dan siswa akan berperan penuh dalam pembelajaran ini. Bamboo Dancing dan Jigsaw memiliki kesamaan dimana pembelajaran ini dilakukan secara berkelompok dan siswa akan berperan sebagai informan bagi teman-teman sejawat yang lainnya.

Komalasari (2010: 65) menyatakan bahwa Metode Jigsaw merupakan salah satu pembelajaran dengan cara guru membagi siswa ke dalam kelompok belajar kooperatif yang terdiri dari empat orang siswa sehingga setiap anggota bertanggung jawab terhadap penguasaan setiap subtopik yang ditugaskan guru. Model pembelajaran jigsaw pertama kali dikembangkan oleh Aronson guna memberi kesempatan siswa untuk saling berbagi informasi pada kelompok dan orang yang berbeda sesuai dengan informasi awal yang telah dibagikan. Disarankan untuk guru untuk memberi banyak kesempatan kepada siswa untuk berdiskusi dan mengolah informasi dalam pembelajaran Matematika sehingga dapat meningkatkan hasil belajar

Model pembelajaran kooperatif lain yang dapat meningkatkan hasil belajar Matematika siswa adalah Bamboo Dancing (BD). Menurut Anita Lie seperti dikutip dalam Zuraida (2015: 121) Model Pembelajaran Bamboo Dancing (BD) diawali dengan menyimak penyajian informasi materi Matematika dari guru, kemudian siswa belajar dalam kelompok yang berpasang-pasangan atau berhadap-hapan. Materi yang telah didiskusikan kemudian diajarkan kepada anggota-anggota kelompok lain, dengan cara bergeser searah dengan berputarnya jarum jam dan sampai kembali lagi dengan pasangan awal/semula.

Model Jigsaw dan Model Bamboo Dancing (BD) memiliki kesamaan, yaitu kedua model ini bertujuan untuk kegiatan dimana siswa akan saling bertukar informasi, sehingga siswa mampu memahami materi pelajaran yang sedang dilakukan. Perbedaan dari model pembelajaran ini untuk Jigsaw menggunakan kelompok dengan anggota yang berbeda, sedangkan untuk Bamboo Dancing (BD) menggunakan teknik belajar saling berhadapan dan model mirip seperti dua bambu yang berhadapan.

Model pembelajaran Jigsaw dan Bamboo Dancing (BD) akan meningkatkan aktivitas siswa dalam belajar. Aktivitas siswa selama proses belajar mengajar merupakan salah satu indikator adanya semangat atau keinginan untuk belajar. Keaktifan siswa dalam proses belajar menciptakan suatu interaksi di dalam kelas, khususnya antara siswa dengan siswa yang lain. Aktivitas yang terbentuk ini akan mengakibatkan terbentuknya suatu pengetauan dan keterampilan yang akan mengarah pada peningkatan hasil belajar siswa.

Penelitian relevan yang pernah dilakukan oleh Ni Luh Adhe Yanti Lestari, I Gusti Agung Oka Negara dan Siti Zulaikha (2014) dengan judul pengaruh model pembelajaran kooperatif tipe Jigsaw terhadap hsil belajar siswa kelas V SD Gugus I Kuta Badung. Menunjukkan bahwa terdapat perbedaan yang signifikan terhadap hasil belajar IPA antara siswa yang belajar melalui model kooperatif tipe Jigsaw dengan siswa yang belajar menggunakan model konvensional, khususnya pada siswa kelas V SD Gugus I Kuta Badung. 
Selain itu penelitian yang dilakukan oleh Beni Lestari, Suripto, dan Suhartono (2017) melakukan penelitian tentang penerapan model tari bambu (Bamboo Dancing) dengan media kartu dalam peningkatan hasil belajar Pendidikan Kewarganegaraan tentang rganisasii di kelas V SD. Hasil penelitian menunjukkan bahwa penerapan model Tari Bambu dengan media kaartu dapat meningkatkan hasil belajar Okn siswa kelas V SDN 2 Ngasinan.

Berdasarkan penelitian terdahulu tentang model pembelajaran kooperatif Bamboo Dancing dan Jigsaw di atas, peneliti merasa ragu tentang model pembelajaran yang manakah yang paling unggul dan apakah ada perbedaan hasil belajar dengan menggunakan model pembelajaran kooperati tipe Jigsaw dan Bamboo Dancing (BD). Maka peneliti tertarik melakukan penelitian yang berjudul Perbedaan Model Pembelajaran Kooperatif Tipe Bamboo Dancing dan Jigsaw Ditinjau dari Hasil Belajar Matematika Siswa Kelas 4 SD

\section{B. KAJIAN PUSTAKA}

\section{Pengertian Matematika}

Matematika merupakan ilmu yang menjadi dasar dalam menentukan nasib perkembangan teknologi di masa mendatang, karena matematika berperan penting sebagai suatu hal yang melatarbelakangi kemajuan daya pikir manusia (Hanifah dan Mawardi, 2016: 252). Fehr dan Philip (2006: 1) menyatakan bahwa "mathematics has always held a key position in the school curriculum because it has been considered knowledge indispensable to educated man." Dimana matematika adalah kunci utama dalam kurikulum sekolah, karena matematika dianggap sebagai pengetahuan yang tidak dapat dipisahkan dari seseorang. Bahkan matematika merupakan kunci utama dalam segala ilmu pengetahuan. Seperti yang dikatakan oleh Roger Bacon seperti yang dikutip oleh Alfred Boediman (2016: 45), "mathematics is the gate and key of the sciences", bukan hanya sebagai kunci utama tetapi matematika merupakan sebuah gerbang bagi ilmu pengetahuan. Dapat disimpulkan bahwa matematika adalah ilmu yang memegang kunci utama baik dalam perkembangan ilmu pengetahuan dan teknologi yang berisi tentang ilmu deduktif, aksiomatik, formal, hierarkis, abstrak, simbol, dan juga pola.

\section{Pembelajaran Matematika di SD}

Matematika merupakan mata pelajaran yang diajarkan disemua jenjang pendidikan mulai dari jenjang paling dasar yaitu SD hingga SMA dan bahkan jenjang paling tinggi yaitu kuliah juga mengajarkan matematika dalam pembelajarannya. Seperti yang dikemukakan oleh Fehr dan Philip (2006), matematika merupakan kunci utama dalam suatu kurikulum pembelajaran, bahkan Roger Bacon menyebutkan kalau matematika merupakan sebuah gerbang dan juga sebuah kunci. Makadari itu matematika perlu diajarkan dari jenjang pendidikan dasar yaitu Sekolah Dasar (SD). Pemberlajaran Matematika di SD diharapkan mampu mendorong siswa untuk menunjukkan sikap positif bermatematika yaitu logis, cermat dan teliti, jujur, bertanggung jawab, dan tidak mudah menyerah dalam menyelesaikan masalah, sebagai wujud implementasi kebiasaan dalam inkuiri dan eksplorasi matematika juga memiliki rasa ingin tahu, semangat belajar yang kontinu, percaya diri, dan ketertarikan pada matematika, yang terbentuk melalui pengalaman belajar. Sehingga matematika di SD diharapkan dapat membantu siswa dalam menyelesaikan suatu permasalahan matematika dengan mengkombinasikan antara pengetahuan dan juga pengalaman.

Dalam pembelajaran matematika siswa akan membangun pengalaman belajarnya sendiri. Guna membangun pengalaman siswa secara langung pembelajaran akan berpusat pada siswa dimana matematika akan memberikan peluang untuk siswa dalam berusaha dan mencari pengalaman dalam matematika sebagai proses yang dirancan untuk menciptakan suasana belajar matematika memungkinkan siswa untuk belajar sehingga tujuan dalam pembelajaran matematika akan tercapai dengan maksimal (Wahyudi dan Kriswandani, 2013: 13).

\section{Model Pembelajaran Kooperatif}

Suatu pembelajaran harus dirancang sedemikian rupa agar siswa termotivasi dengan belajar. Salah satu cara agar menarik keingin tahuan siswa yaitu menggunakan suatu model pembelajaran. Menurut Mawardi (2018: 29) model pembelajaran merupakan suatu kerangka konseptual yang digunakan untuk mencapai tujuan/kompetensi, dan sebagai pedoman dalam suatu proses pembelajaran karena berisi 
langkah/sintak pembelajaran yang sistematis. Ada berbagai macam model pembelajaran salah satunya yaitu model pembelajaran kooperatif.

Menurut Miftahul Huda (2014: 111) Pembelajaran Kooperatif adalah cara untuk mengembangkan suatu pembelajaran yaitu dengan kerjasamaa yang akan meningkatkan motivasi dimana jauh lebih besar daripada melalui lingkungan kompetitif individual. Sedangkan menurut Agus Suprijono (2012: 54) Pembelajaran Kooperatif adalah

Menurut Agus Suprijono (2012) model pembelajaran kooperatif terdiri dari beberapa tipe, yaitu Student Teams Achievement Divisions (STAD), Jigsaw, Group Investigation, Teams Games Turnaments (TGT), Team Assisted Individualization (TAI), Snowball Throwing, Numbered Head Together (NHT), Cooperative Integrated Reading and Composition (CIRC), Make a Macth, Think Pair Share (TPS), Course Review Horay (CRH), Talking Stick dan sebagainya.

Berdasarkan beberapa model pembelajaran kooperatif di atas, diputuskan untuk menggunakan model pembelajaran kooperatif tipe Jigsaw dan model pembelajaran kooperatif tipe Bamboo Dancing (BD), karena dalam kedua model pembelajaran ini meningkatkan keaktifan siswa dalam memperoleh informasi dan juga model pembelajaran ini bertujuan untuk meningkatkan hasil belajara siswa pada mata pelajaran Matematika di SD, karena dalam kedua model pembelajaran ini terdapat unsur kerja sama dan interaski untuk saling memahami materi yang telah diberikan oleh guru

\section{Model Pembelajaran Bamboo Dancing}

Model pembelajaran Bamboo Dancing (BD) bertujuan saling berbagi informasi dari satu siswa ke siswa yang lain. Model BD juga menggunakan metode berkelompok dimana siswa akan saling berbagi informasi dari teman yang berbeda-beda. Menurut Anita Lie seperti dikutip dalam Zuraida (2015: 121) model pembelajaran BD (Bamboo Dancing) diawali dengan menyimak penyajian informasi materi Matematika dari guru, keumdian siswa belajar dalam kelompok yang berpasangpasangan atau berhadap-hadapan. Sedangkan menurut Agus Suprijono (2012: 98) Model pembelajaran BD melalui kegiatan sumbang saran, model pembelajaran ini dimaksudkan untuk mengaktifkan struktur kognitif yang telah dimiliki oleh peserta didik agar lebih siap dalam menghadapi pelajaran yang baru. Selanjutnya Miftahul Huda (2014: 250) menyatakan bahwa model pembelajaran BD merupakan model pembelajaran yang memungkinkan siswa saling berbagi informasi pada waktu yang bersamaan. Berdasarkan pendapat beberapa ahli di atas dapat disimpulkan bahwa Pembelajaran Bamboo Dancing merupakan pembelajaran yang akan mengaktifkan struktur kognitif peserta didik dimana pada waktu awal peserta didik akan menyimak penyajian informasi dari guru dan kemudian siswa akan belajar dalam kelompok yang berpasang-pasangan atau berhada-hadapan dan siswa akan saling berbagi informasi pada waktu yang bersamaan.

Kelebihan model Bamboo Dancing menurut Shoimin (2014: 33) yaitu mampu meningkatkan kecerdasan sosial dalam hal kerjasama antar siswa, meningkatkan toleransi antar sesama, dan memudahkan siswa untuk saling bertukar pengalaman serta pengetahuan dalam proses pembelajaran. Sedangkan kekurangan model pembelajaran Bamboo Dancing menurut Shoimin (2014: 33) yaitu memerlukan waktu yang cukup panjang, menjadikan siswa cenderung untuk bermain daripada belajar, dan menyulitkan proses belajar mengajar karena kelompok yang terbentuk terlalu besar.

Langkah-langkah model pembelajaran Bamboo Dancing menurut Anita Lie seperti dikutip dalam Zuraida (2015: 121) yaitu sebagai berikut: 1) Separuh kelas (atau seperempat jika jumlah siswa terlalu banyak) berdiri sejajar. Jika terdapat ruang yang luas, siswa bisa berjajar di depan kelas. Bisa juga siswa berdiri berjajar di sela-sela deretan bangku. 2) Separuh kelas lainnya saling berjajar dan menghadap jajaran yang pertama. 3) Dua siswa yang saling berpasangan dan berjajaran berbagi informasi. 4) Kemudian, dua siswa yang berdiri di ujung sala satu jajaran pindah ke ujung yang satunya di jajarannya. Jajaran ini akan terus bergeser. Masing-masing siswa mendapatkan pasangan yang baru untuk berbagi .

\section{Model Pembelajaran Jigsaw}

Menurut Sugiyanto (2008: 35) pembelajaran kooperatif adalah pembelajaran yang berfokus pada pembelajaran yang menggunakan kelompok kecil dalam pembelajaran untuk membuat siswa bekerjasama untuk memaksimalkan kondisi 
belajar guna mencapai tujuan pembelajaran. Model pembelajaran Jigsaw merupakan salah satu tipe moel pembelajaran kooperatif yang menggunakan suatu kelompok dalam pembelajaran.. Siswa akan mempunyai tanggung jawab sendiri terhadap materi yang akan mereka pelajari. Arends (2008: 13) berpendapat bahwa model pembelajaran kooperatif tipe Jigsaw merupakan model pembelajaran dimana siswa akan belajar dalam kelompok kecil yang terdiri dari $4-6$ orang secara heterogen. Siswa akan mempunyai tanggung jawab sendiri terhadap materi yang akan mereka pelajari. Metode Jigsaw merupakan salah satu pembelajaran dengan cara guru membagi siswa ke dalam kelompok belajar kooperatif yang terdiri dari empat orang siswa sehingga setiap anggota bertanggung jawab terhadap penguasaan setiap subtopik yang ditugaskan guru (Komalasari, 2010: 65).

Berdasarkan beberapa pendapat di atas dapat disimpulkan bahwa model pembelajaran kooperatif tipe Jigsaw merupakan pembelajaran yang menggunakan kelompok kecil dalam suatu pembelajaran dimana siswa akan memiliki tanggung jawab pada setiap subtopik yang diberikan guru untuk mengolah informasi dengan cara mereka sendiri serta meningkatkan keterampilan komunikasi siswa.

Menururt Miftahul Huda (2014: 204) metode pembelajaran kooperatif tipe Jigsaw memiliki kelebihan yaitu dimana model pembelajaran kooperatif tipe Jigsaw menggabungkan aktivitas membaca, menulis, mendengarkan, dan berbicara. Aktivitas ini akan membuat guru memahami kemampuan siswa dan pengalaman siswa dan membantu siswa dalam mengaktifkan pola gabungan aktivitas dari moel pembelajaran Jigsaw, sehingga pembelajaran akan lebih bermakna. Model pembelajaran Jigsaw akan membantu siswa untuk belajar mengkomunikasikan matematika. Siswa akan belajar mendengarkan suatu informasi dari teman yang lain dan juga siswa juga akan berbicara kepada teman yang lain untuk mengutarakan informasi yang telah mereka dapatkan.

Langkah-langkah model pembelajaran Jigsaw menurut Trianto (2011: 73) yaitu: a) Pembagian kelompok secara acak/heterogen. b). Pembagian materi telah dibagi menjadi beberapa subtopik dan diberikan kepada masing-masing kelompok. c). Mempelajari subtopik yang telah diberikan kepada kelompok. d). Berkumpul dalam tim ahli atau tim yang memiliki subtopik yang sama sehingga siswa mampu membahas subtopik secara mendalam. e). Kembali ke kelompok asal untuk memberikan informasi kepada teman yang lain tentang apa yang telah dipelajari di kelompok ahli. f). Kuis individu yang diberikan oleh guru dan dikerjakan secara individu.

\section{Hasil Belajar}

Pencapaian suatu tujuan pembelajaran dari suatu kegiatan pembelajaran dapat dilihan melalui hasil belajar. Menurut Sudijono (2012: 32) hasil belajar merupakan sebuah tindakan evaluasi yang dapat mengungkap aspek proses berpikir (cognitive domain) juga dapat mengungkap aspek nilai atau sikap (affective domain) dan aspek keterampilan (psychomotor domain) yang melekat pada diri setiap individu peserta didik. Artinya melalui hasil belajar, pencapaian siswa setelah melalui pembelajaran dapat diketahui. Hasil belajar menurut Budi (2016: 112) adalah gambaran efektivitas dalam suatu pembelajaran. Dari beberapa ahli yang telah disebutkan, dapat dirumuskan bahwa hasil belajar yaitu keefektivan dalam suatu pembelajaran yang diraih oleh siswa berupa kemampuan kognitif, kemampuan afektif dan kemampuan psikomotor.

Pengukuran hasil belajar dilakukan untuk mengetahui tingkat pencapaian kompetensi yang terjadi pada siswa. Melalui pengukuran yang dilakukan oleh guru, siswa mampu mengetahui sejauh mana kemampuan yang dimiliki dan siswa tau dimana kekurangan dalam mempelajari suatu pembelajaran sehingga siswa dapat memperbaiki diri.

\section{Kajian Penelitian yang Relevan}

Olyn Suyanti Darmada, Semara Putra, dan I. Gd. Meter (2013) melakukan penelitian tentang pengaruh model pembelajaran Cooperative Learning tipe Jigsaw terhadap hasil belajar IPS siswa kelas IV di SDN 1 dan 2 Rendang. Dalam penelitian ini menunjukkan hasil bahwa terdapat perbedaan hasil belajar yang signifikan antara siswa yang mengikuti model pembelajaran cooperative learning tipe jigsaw dengan hasil belajar siswa yang menggunakan model pembelajaran konvensional, dengan $t_{\text {hitung }}$ sebesar 4,78 sedangkan $t_{\text {tabel }}$ sebesar 2,00. Dapat disimpulkan bahwa terdapat pengaruh model 
pembelajaran cooperative learning tipe jigsaw terhadap hasil belajar IPS di SD Negeri 2 Rendang.

Siti Maisaroh dan Rosalia Susila Purwanti (2012) melakukan penelitian tentang keefektifan model pembelajaran kooperatif tipe Jigsaw dan Team Games Tournament (TGT) terhdap hasil belajar IPS di SD MBS Kabupaten Bantul Yogyakarta. Hasil dari penelitian ini yaitu bahwa model pembelajaran kooperatif tipe Jigsaw lebih efektif daripada model pembelajaran TGT, dibuktikan dengan hasil dari analisis posttest $t_{\text {hitung }}$ $=2,196$ dan $t_{\text {tabel }}=1,99$ dan perbedaan rata-rata model pembelajaran Jigsaw yaitu 80,82 dan model pembelajaran TGT yaitu 75,05.

Ardiati, Mastar Asran, dan Nurhadi (2014) melakukan penelitian tentang pengaruh penggunaan tipe bamboo dancing dengan hasil pembelajaran IPS di kelas V. Hasil penelitian menemukan bahwa terdapat pengaruh tipe bamboo dancing terhadap hasil belajar siswa kelas V SD Negeri 15 Pontianak Selatan pada mata pelajaran Ilmu Pengetahuan Sosial. Hal ini dibuktikan dengan hasil belajar siswa saat sebelum menggunakan model pembelajaran bamboo dancing menunjukkan rata-rata sebesar 51,07 dan rata-rata hasil belajar saat setelah menggunakan bamboo dancing sebesar 70,17.

Candra Dewi (2016) melakukan penelitian tentang penerapan metode Bamboo Dancing untuk meningkarkan hasil belajar IPS pada siswa kelas V Sekolah Dasar. Hasil yang diperoleh dari penelitian yaitu rata-rata pada saat prasiklus menunjukkan hasil di bawah KKM (60) yaitu 55. Pada saat siklus I ada peningkatan pada rata-rata kelas yaitiu sebesar 65 dan pada siklus II mengalami peningkatan lagi yaitu sebesar 81 . Hasil ini menunjukkan bahwa metode Bamboo Dancing dapat meningkatkan hasil belajar siswa kelas V SD.

Rizki Khamidah, Alben Ambarita, dan Sowiyah (2017) melakukan penelitian tentang pengaruh pembelajaran kooperatif tipe Tari Bambu terhadap Hasil Belajar Tema Ekosistem. Penelitian ini dilakukan pada tema ekosistem kelas V SDN 8 Metro Timur. Hasil penelitian ini menunjukkan bahwa ada pengaruhu pada penerapan model pembelajaran kooperatif tipe tari bambu terhadap hasil belajar siswa pada tema ekosistem kelas $\mathrm{V}$ SDN 8 Metro Timur. Dibuktikan dengan nilai posttest pada kelas eksperimen sebesar 73,44 sedangkan pada kelas kontrol sebesar 66,07. Nilai rata-rata $N$-Gain siswa kelas eksperimen sebesar 0,92 dan nilai $N$-Gain pada kelas kontrol sebesar 0,61 . Berdasarkan hasil penghitungan hipoptesis diperoleh nilai sig (2 tailed) 0,001.

\section{METODE PENELITIAN}

Jenis penelitian yang dilakukan yaitu penelitian eksperimen semu (quasi research). Eksperimen semu (quasi research) merupakan bentuk sederhana dari eksperimen murni (true research). Penelitian eksperimen semu menggunakan desain Nonequivalent Control Group Design. Penggunaan desain penelitian eksperimen semu pada kelompok eksperimen dan kelompok kontrol. Pada kelompok eksperimen 1 pada penelitian ini menggunakan model pembelajaran Jigsaw dan sedangkan pada kelompok eksperimen 2 sebagai kelompok untuk menerapkan model pembelajaran Bamboo Dancing. Dalam penelitian ini kelompok kelas eksperimen dan kelompok kelas kontrol mendapatkan pelajaran yang sama pada mata pelajaran Matematika yaitu tentang "Bangun Segi Banyak Beraturan", namun menggunakan penerapan model yang berbeda.

Sampel pada penelitian ini adalah siswa kelas 4 Gugus Diponegoro. Namun, peneliti hanya akan meneliti 3 SD saja dari 8 SD negeri yang ada yaitu SDN Sidorejo Lor 03 sebagai SD Inti yang akan diberi perlakuan kelas 4A sebagai kelas eksperimen 1 dan kelas 4B sebagai kelas eksperimen 2/kelas kontrol, SDN Sidorejo Lor 05 sebagai SD Imbas yang akan diberi perlakuan kelas 4A sebagai kelas eksperimen 1 dan kelas 4B sebagai kelas eksperimen 2. SDN Blotongan 02 sebagai SD Imbas Jauh akan diberi perlakuan kelas 4A sebagai kelas eksperimen 1 dan kelas 4B sebagai kelas eksperimen 2 .

Teknik pengulmpulan data pada penelitian ini menggunakan teknik pengumpulan data tes dan non tes. Untuk pengambilan data secara tes menggunakan tes formatif berupa tes pilihan ganda yang terdiri dari pretest dan posttest. Teknik tes digunakan untuk mengukur kemampuan kognitif siswa. Menurut Mawardi (2014: 118) penilaian pengetahuan merupakan penilaian yang berkaitan dengan aspek penguasaan materi pembelajaran secara kognitif. Sedangkan untuk teknik non tes menggunakan lembar observasi guru dan lembar observasi siswa.

Teknik analisis data berupa teknik analisis data deskriptif dan teknik analisis data statistik Uji T. Teknik analisis data deskriptif terdiri aras teknik 
analisis data deskriptif dan distribusi frekuensi, untuk teknik analisis data statistik terdiri dari uji prasyarat yang berupa uji normalitas dan homogenitas dan uji hipotesis yang menggunakan uji beda atau Uji T (T-Test).

\section{HASIL DAN PEMBAHASAN}

Penelitian dilakukan di kelas 4A dan 4B diSDN Sidorejo Lor 03, SDN Sidorejo Lor 05, dan SDN Blotongan 02. Materi yang diajarkan adalah materi Bangun Datar (Persegi, Persegi Panjang, dan Segitiga). Pertemuan dilakukan sebanyak $2 x$ pada setiap kelas. Alokasi waktu setiap pertemuan yaitu 4x35 menit. Penelitian dilakukan secara team teaching dimana guru dan peneliti melakukan pergantian menjadi observer. Berikut hasil dan pembahasan hasil penelitian.

\section{Tingkat Hasil Belajar Matematika Siswa}

Kelas 4A $\begin{aligned} & \text { Menggunakan } \\ & \text { Pembelajaran Jigsaw sebagai }\end{aligned}$ Kelompok
Eksperimen/Eksperimen 1

Tingkat hasil belajar Matematika siswa dipaparkan melalui statistik deskriptif dari hasil pretest dan posttest yang terdiri dari rata-rata, nilai tertinggi, nilai terendah, standar deviasi.

TABEL 1

STATISTIK DESKRIPTIF NILAI PRETEST DAN POSTTEST KELOMPOK EKSPERIMEN 1

\begin{tabular}{lrcrrr}
\hline & N & Mini & Max & Mean & $\begin{array}{c}\text { Std. } \\
\text { Deviation }\end{array}$ \\
\hline Nilai_Pretest & 45 & 40,00 & 95,00 & 64,4444 & 13,70228 \\
\hline Nilai_Posttest & 45 & 45,00 & 100,00 & 80,5778 & 15,59500 \\
\hline $\begin{array}{l}\text { Valid N } \\
\text { (listwise) }\end{array}$ & 45 & & & & \\
\hline
\end{tabular}

Berdasakan Tabel 1 dapat dilihat bahwa nilai rata-rata kelas eksperimen 1 (niali pretest) sebelum proses pembelajaran dengan perlakuan model pembelajaran Jigsaw sebesar 64,4444 dengan standar deviasi 13,70228. Setelah pelaksanaan pembelajaran dengan menerapkan model pembelajaran Jigsaw nilai rata-rata hasil posttest meningkat menjadi 80,5778 dengan standar deviasi 15,59500 . Pada saat pretest nilai tertinggi yang didapatkan yaitu 95 dan nilai terendah 40 , sedangkan pada saat posttest nilai tertinggi yang diperoleh yaitu 100 dan nilai terendah yaitu 45. Jumlah siswa yang mengikuti pretest dan posttest sebanyak 45 siswa.
2. Tingkat Hasil Belajar Matematika Siswa Kelas 4B Menggunakan Model Pembelajaran Bamboo Dancing sebagai Keleompok Kontrol/Kelompok Eksperimen 2

Tingkat hasil belajar Matematika siswa disajikan melalui statistik dekriptif dari hasi pretest dan posttest yang terdiri dari rata-rata, nilai tertinggi, nilai terendah, standar deviasi

TABEL 2

STATISTIK DESKRIPTIF NILAI PRETEST DAN POSTTEST KELOMPOK EKSPERIMEN 2

\begin{tabular}{lcrrrc}
\hline & N & Minimum & $\begin{array}{c}\text { Maximu } \\
\mathrm{m}\end{array}$ & Mean & $\begin{array}{c}\text { Std. } \\
\text { Deviati } \\
\text { on }\end{array}$ \\
\hline $\begin{array}{l}\text { Nilai_P } \\
\text { retest }\end{array}$ & 45 & 40,00 & 95,00 & 65,11 & 12,27 \\
\hline $\begin{array}{l}\text { Nilai_P } \\
\text { osttest }\end{array}$ & 45 & 50,00 & 100,00 & 73,67 & 14,36 \\
\hline
\end{tabular}

Berdasarkan Tabel 2 dapat diketahui bahwa nilai rata-rata kelas eksperimen 2 (nilai pretest) pada saat sebelum pembelajaran dengan perlakuan model Bamboo Dancing sebesar 65,1111 dengan standar deviasi 12,27011. Setelah pelaksanaan pembelajaran dengan menggunakan model Bamboo Dancing didapatkan nilai posttest meningkat menjadi 73,6667 dengan standar deviasi 14,35745. Nilai tertinggi yang dicapai pada saat pretest adalah 95 dan nilai terendah yaitu 40,00 sedangkan saat posttest nilai tertinggi mencapai 100 dan nilai terendah yaitu 50,00. Jumlah siswa yang mengikuti pretest dan posttest yaitu sebanyak 45 siswa.

\section{Deskripsi Komparasi Hasil Pengukuran}

Deskripsi komparasi dalam penelitian ini memaparkan perbedaan hasil pengukuran dari kelompok eksperimen 1 dan eksperimen 2 berdasarkan nilai pretest dan nilai posttest. Deskripsi komparai disajikan dalam bentuk tabel dan grafik berikut.

TABEL 3

KOMPARASI HASIL PNGUKURAN KELOMPOK EKSPERIMEN 1 DAN KELOMPOK EKSPERIMEN 2

\begin{tabular}{llcl}
\hline \multirow{2}{*}{ Tahap } & \multicolumn{2}{c}{ Rata-rata kelompok } & \multirow{2}{*}{$\begin{array}{c}\text { Selisih } \\
\text { Pengukuran }\end{array}$} \\
\cline { 2 - 3 } & $\begin{array}{c}\text { Eksperimen } \\
1\end{array}$ & $\begin{array}{c}\text { Eksperimen } \\
\text { skor }\end{array}$ \\
\hline Pretest & 64,444 & 65,111 & 0,667 \\
\hline Posttest & 80,5778 & 73,6667 & 6,9111 \\
\hline
\end{tabular}


Berdasarkan Tabel 3 di atas dapat diketahui bahwa terdapat perbedaan nilai rata-rata tahap awal yaitu pretest yang ditunjukkan antara selisih skor kelompok eksperimen 1 dan eksperimen 2 yaitiu sebesar 0,667 dimana rata-rata kelompok eksperimen 2 lebih ungguk daripada kelompok eksperimen 1. Pada tahap akhir perngukuran (posttest) juga tedapat perbedaan nilai rata-rata yang ditunjukkan adanya selisih skor antara kelompok eksperimen 1 dan eksperimen 2 yaitu sebesar 6,9111 dimana nilai rata-rata kelompok eksperimen 1 (penerapan model pembelajaran Jigsaw) lebih untuk daripada kelompok eksperimen 2 (penerapan model pembelajaran Bamboo Dancing). Secara singkat akan disajikan dalam bentuk grafik berikut.

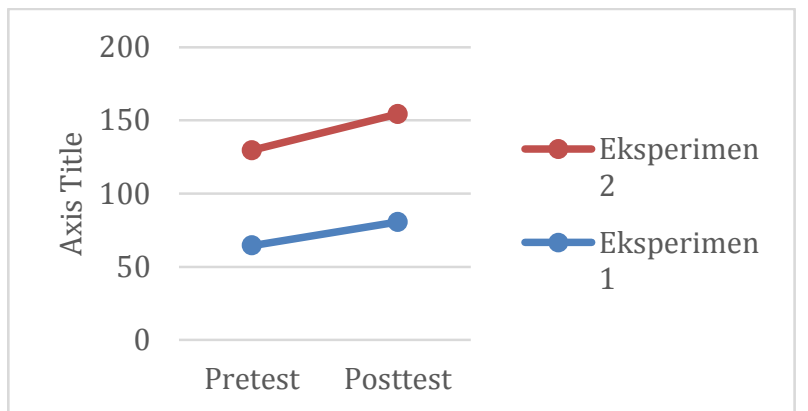

Gambar 1. Grafik Deskripsi Komparasi Eksperimen 1 dan Eksperimen 2

\section{Hasil Uji Perbedaan Rata-Rata atau Uji T Hasil Belajar Matematika}

Setelah uji prasyarat (uji normalitas dan uji homogenitas) terpenuhi, dan dan data posttest dapat digunakan untuk uji T sebagai acuan untuk menguji hipotesis untuk melihat apakah rata-rata nilai kelompok eksperimen 1 lebih unggul secara signifikan dari pada kelompok eksperimen 2.

Di bawah ini disajikan hasil uji $\mathrm{T}$ (uji beda ratarata) kelompok eksperimen 1 dan kelompok eksperimen 2 pada SD di Gugus Diponegoro Kecamatan Sidorejo Salatiga.

TABEL 4

HASIL UJI T KELOMPOK EKSPERIMEN 1 DAN EKSPERIMEN 2

\begin{tabular}{ccccc}
\hline $\begin{array}{c}\text { Levene's Test for } \\
\text { Equality of Variances }\end{array}$ & \multicolumn{3}{c}{ t-test for Equality of Means } \\
\hline F & Sig. & t & df & Sig. (2-tailed)
\end{tabular}

,196 ,659 2,187

88

, 031

Analisis uji beda Uji T menggunakan equal variances assumed (asumsi varian sama) dari tabel 4.11 di atas dapat dilihat bahwa nilai t hitung adalah 2,187 dengan sig. (2-tailed) 0,031 dan sig. (1-tailed) 0,0155 dan df sebesar 88 sehingga didapat $\mathrm{t}$ tabel 1,684 . Nilai probablilitas $<0,05$ maka $\mathrm{H}_{0}$ ditolak dan $\mathrm{H}_{a}$ diterima, dapat dikatakan juga bahwa hasil belajar kelompok eksperimen 1 lebih tinggi daripada kelompok eksperimen 2 .

\section{Pembahasan}

Penelitian telah dilakukan di SD Gugus Diponegoro Kec. Sidorejo yaitu SDN Sidorejo Lor 03, SDN Sidorejo 05, dan SDN Blotongan 02. Pada masing-masing SD terdapat dua kelas yaitu kelas $4 \mathrm{~A}$ dan kelas 4B, untuk kelas A sebagai kelas eksperimen 1 dengan melaksanakan kegiatan pembelajaran menggunakan model Jigsaw dan kelas 4B sebagai kelas eksperimen 2 dengan melaksanakan pembelajaran menggunakan model Bamboo Dancing berjalan lancar sesuai dengan sintag dan Rencana Pelaksanaan Pmbelajaran.

Guru telah melaksanakan sintak pembelajaran sesuai dengan model. Penelitian difokuskan pada rumusan masalah seperti yang telah dijabarkan pada bagian sebelumnya yaitu apakah dalam penerapan model pembelajaran kooperatif tipe Jigsaw lebih tinggi secara signifikan daripada model pembelajaran kooperatif tipe Bamboo Dancing ditinjau dari hasil belajar Matematika siswa kelas 4 SD Gugus Diponegoro Kota Salatiga.

Hasil uji prasyarat dari kedua kelompok penelitian adalah homogen karena nilai pretest kelompok eksperimen dan kontrol sebesar 0,298 > 0,05 dan nilai posttest sebesar 0,643 >0,05. Dapat disimpulkan dari hasil uji prasyarat bahwa kedua varian tersebut (kelas eksperimen 1 dan eksperimen 2) homogen. Untuk hasil uji normalitas pretest-posttest secara keseluruhan $>0,05$ sehingga dapat disimpulkan kelompok eksperimen 1 dan eksperimen 2 berdistribusi normal.

Analisis deskriptif dari perolehan kelompok eksperimen 1 dapat dilihat dari hasil pretest sebesar 64,444 meningkat menjadi 80,5778 dilihat dari hasil nilai posttest. Sedangkan pada kelompok eksperimen 2 juga mengalami peningkatan yaitu perolehan skor pretest sebesar 65,111 dan hasil posttest sebesar 73,6667

Analisis berikutnya yaitu uji beda (uji T) dengan nilai t hitung adalah 2,187 dengan sig. (2tailed) 0,031 dan sig. (1-tailed) 0,0155 dan df sebesar 88 sehingga didapat $\mathrm{t}$ tabel 1,684 . Nilai probablilitas $<0,05$ maka $\mathrm{H}_{0}$ ditolak dan $\mathrm{H}_{\mathrm{a}}$ diterima, dapat dikatakan juga bahwa hasil belajar kelompok 
eksperimen 1 lebih tinggi daripada kelompok eksperimen 2. Berdasarkan hasil dari uji hipotesis yang menggunakan analisis uji beda (uji T) dapat dikatakan bahwa model pembelajaran Jigsaw lebih unggul secara signifikan daripada model pembelajaran Bamboo Dancing yang ditinjau dari hasil belajar Matematika siswa.

Penerapan model pembelajaran Jigsaw dalam penelitian lebih unggul dalam memberikan pengaruh terhadap hasil belajar siswa dibanding model pembelajaran Bamboo Dancing. Model pembelajaran Jigsaw mempunyai sintak pembelajaranyang menarik sehingga siswa dapat melakukan kegiatan bertukar informasi dengan teman dari kelompok lain, sehingga tidak hanya melakukan pertukaran informasi dengan teman yang sama. berikut adalah sintak model pembelajaran Jigsaw yaitu menurut Trianto (2011: 73) dimana langkah-langkahnya sebagai berikut: a) Pembagian kelompok secara acak/heterogen. b). Pembagian materi telah dibagi menjadi beberapa subtopik dan diberikan kepada masing-masing kelompok. c). Mempelajari subtopik yang telah diberikan kepada kelompok. d). Berkumpul dalam tim ahli atau tim yang memiliki subtopik yang sama sehingga siswa mampu membahas subtopik secara mendalam. e). Kembali ke kelompok asal untuk memberikan informasi kepada teman yang lain tentang apa yang telah dipelajari di kelompok ahli. f). Kuis individu yang diberikan oleh guru dan dikerjakan secara individu.

Tidak kalah menarik dengan model pembelajaran Jigsaw model pembelajaran Bamboo Dancing dengan diliat dari hasil posttest dengan selisih 6 poin juga memiliki sintak pembelajaran yang hampir sama dengan model pembelajaran Jigsaw, yaitu sama-sama melakukan pertukaran informasi dengan teman yang berbeda. Langkahlangkah model pembelajaran Bamboo Dancing menurut Anita Lie seperti dikutip dalam Zuraida (2015: 121) yaitu: 1) Separuh kelas (atau seperempat jika jumlah siswa terlalu banyak) berdiri sejajar. Jika terdapat ruang yang luas, siswa bisa berjajar di depan kelas. Bisa juga siswa berdiri berjajar di sela-sela deretan bangku. 2) Separuh kelas lainnya saling berjajar dan menghadap jajaran yang pertama. 3) Dua siswa yang saling berpasangan dan berjajaran berbagi informasi. 4) Kemudian, dua siswa yang berdiri di ujung sala satu jajaran pindah ke ujung yang satunya di jajarannya.
Jajaran ini akan terus bergeser. Masing-masing siswa mendapatkan pasangan yang baru untuk berbagi.

Sejalan dengan hasil penelitian yang dilakukan oleh Olyn Suyanti Darmada, Semara Putra, dan I. Gd. Meter (2013) menunjukkan bahwa $t_{\text {hitung }}=4,78$ dan $t_{\text {tabel }}=2,00$ dan memberikan kesimpulan bahwa model pembelajaran kooperatif tipe Jigsaw lebih memberikan pengaruh terhadap hasil belajar IPS di SDN 2 Rendang.

Selain dari beberapa peneliti di atas, Siti Maisaroh dan Rosalia Susila Purwanti juga sependapat bahwa model pembelajaran Jigsaw lebih efektif terhadap hasil belajar IPS siswa. Hal ini dibuktikan dengan hasil penelitian yaitu pada analisis posttetst $t_{\text {hitung }}=2,196$ dan $t_{\text {tabel }}=1,99$ diperkuat dengan hasil rata-rata pada kedua model pembelajaran. Rata-rata model pembelajaran Jigsaw yaitu 80,82 dan rata-rata model pembelajaran TGT yaitu 75,05 ini membuktikan bahwa model pembelajaran Jigsaw lebih tinggi daripada model pembelajaran TGT.

Tidak begitu dengan penelitian yang dilakukan oleh Rizki Khamidah, Alben Ambarita, dan Sowiyiah (2017) dalam penerapan model pembelajaran Bamboo Dancing memberikan pengaruh terhadap hasil belajar siswa kelas 5 SDN Metro Timur yaitu dengan Dibuktikan dengan nilai posttest pada kelas eksperimen sebesar 73,44 sedangkan pada kelas kontrol sebesar 66,07. Nilai rata-rata $N$-Gain siswa kelas eksperimen sebesar 0,92 dan nilai $N$-Gain pada kelas kontrol sebesar 0,61 . Berdasarkan hasil penghitungan hipoptesis diperoleh nilai sig (2 tailed) 0,001 .

Selain itu Candra Dewi (2016) juga menyebutkan bahwa model pembelajaran Bamboo Dancing lebih efektf untuk meningkatkan hasil belajar IPS siswa. pada penelitiannya yang berjudul Penerappan Metode Bamboo Dancing untuk Meningkatkan Hasil Belajar IPS pada Siswa Kelas 5 SD, menunjukkan rata-rata pada saar prasiklus di bawah KKM. Rata-rata saat prasiklus yaitu 55 sedangkan KKM dari pelajaran IPS yaitu 60. Pada saat siklus I ada peningkatan rata-rata kelas yaitu menjadi 65 dan pada siklus II rata-rata menjadi 81. Hal ini menunjukkan bahwa model pembelajaran Bamboo Dancing dapat meningkatkan hasil belajar IPS siswa kelas 5 SD.

Pemaparan hasil analisis data dapat disimpulkan bahwa terdapat perbedaan nilai awal 
dan nilai akhir dalam penggunaan model pembelajaran Jigsaw dan Bamboo Dancing dalam pencapaian hasil belajar siswa kelas 4 SD Gugus Diponegoro Kecamatan Sidorejo. Namun hasil dalam penelitian menunjukkan bahwa dalam penerapan model pembelajaran kooperatif tipe Jigsaw lebih tinggi secara signifikan daripada model pembelajaran Bamboo Dancing terhadap hasil belajar Matematika siswa kelas 4 SD di Gugus Kec. Sidorejo Salatiga.

\section{E. SIMPULAN DAN SARAN}

\section{Simpulan}

Berdasarkan analisis dan pembahasan yang telah dilakukan pada bab sebelumnya, dapat disimpulkan bahwa penerapan model pembelajaran kooperatif tipe Jigsaw lebih unggul secara signifikan daripada model pembelajaran kooperatif tipe Bamboo Dancing terhadap hasil belajar Matematika siswa kelas 4 SD Gugus Diponegoro Kecamatan Sidorejo Salatiga. Hal ini dapat dibuktikan melalui uji beda rata-rata nilai posttest (Uji T) diperoleh hasil thitung yaitu 2,187 dan $t_{\text {tabel }}$ yaitu 1,644 dengan signifikansi 0,155 $<0,05$, maka $\mathrm{H}_{0}$ ditolak dan $\mathrm{H}_{a}$ diterima. Artinya adalah bahwa hasil belajar Matematika dalam penerapan model pembelajaran Jigsaw lebih unggul daripada model pembelajaran Bamboo Dancing di SD Gugus Diponegoro Salatiga. Pernyataan ini diperkuat dengan rata-rata nilai posttest pada kelompok eksperimen 1 dengan penggunaan model pembelajaran Jigsaw yaitu 80,5778 dan sedangkan pada kelompok eksperimen 2 dengan penggunaan model pembelajaran Bamboo Dancing adalah 73,6667 .

\section{Saran}

Berdasarkan hasil penelitian yang telah dilakukan, maka terdapat beberapa saran dari peneliti untuk:

a. Guru

Berdasarkan hasil penelitian, hasil belajar dengan menggunakan model pembelajaran Jigsaw lebig tinggi secara signifikan, maka guru diharapkan dapat menerapkan model pembelajaran Jigsaw untuk meningkatkan hasil belajar matematika dan disesuaikan dengan materi pembelajaran yang akan diajarkan

b. Kepala Sekolah

Diharapkan kelapa sekolah mampu mengadakan pelatihan atau mensosialisasikan model pembelajaran Jigsaw kepada guru kelas baik dari kelas bawa sampai kelas atas. Dengan demikian model pembelajaran Jigsaw dapat digunakan untuk mengembangkan pembelajaran yang tidak hanya kreatif, aktif , dan inovatif tetapi juga menyenangkan.

c. Peneliti Selanjutnya

Adanya penelitian dapat digunakan sebagai referensi untuk mengembangkan penelitian yang serupa selanjutnya.

\section{UCAPAN TERIMA KASIH}

Penulis mengucapkan terimakasih kepada semua pihak yang telah membantu dalam proses penelitian. Terutama kepada dosen pembimbing dan juga teman-teman yang membantu dalam proses pelaksanaan penelitian. Terimakasih juga kepada SDN Sidorejo Lor 03, SDN Sidorejo Lor 05, dan SDN Blotongan 02 terimakasih telah membantu saya dalam memberikan kesempatan untuk melakukan penelitian.

\section{REFERENSI}

[1] Arends, R. (2008). Learning To Teach Belajar untuk Mengajar. Yogyakarta: Pustaka Belajar.

[2] Astuti, Suhandi. (2016). Penerapan Supervisi Akademik untuk Meningkatkan Kompetensi Guru dalam Menyusun Administrasi Penilaian di SD Laboratorium UKSW. Scholaria: Jurnal Pendidikan dan Kebudayaan. 6(1), 117-126)

[3] Boediman, Alfred. (2016). Beyond Me: Unleashing Technopreneurship Potential: Jakarta Pusat: Kesaint Blanc.

[4] Darmada, Olyn Suyanti, Samara Putra, dan I. Gd. Meter. (2013). Pengaruh Model Pembelajaran Cooperative Learning Tipe Jigsaw terhadap Hasil Belajar IPS Siswa Kelas IV di SDN 1 dan 2 Rendang. Mimbar PGSD Undiksha. 1(1). 1-10.

[5] Dewi, Candra. (2016). Implementasi Metode Bamboo Dancing untuk Meningkatkan Hasil Belajar Ilmu Pengetahuan Sosial pada Siswa Kelas V Sekolah Dasar. INDRIA: Jurnal Ilmiah Pendidikan PraSekolah dan Sekolah Awal. 1(1), 1-8.

[6] Fehr \& Philip. (2006). Teaching Modern Mathematics in The Elementary School. London: Addison - Wesley Publishing Company

[7] Huda, M. (2014). Model-Model Pembelajaran dan Pembelajaran. Yogyakarta: Pustaka Pelajar.

[8] Khamidah, Rizki, Alben Ambarita, dan Sowiyah. (2017). Pengaruh Cooperative Learning Tipe Tari Bambu terhadap Hasil Belajar Tema Ekosistem. Jurnal Pedagogi. 5(9), 1-10. 
[9] Kusumawati, Hanifah dan Mawardi. (2016). Perbedaan Penerapan Model Pembelajaran Kooperatif Tipe NHT dan STAD Ditinjau dari Hasil Belajar Siswa. SCHOLARIA: Jurnal Pendidikan dan Kebudayaan. 6(3), 251-263.

[10] Komalasari, K. (2010). Pembelajaran Kontekstual . Bandung: PT Refika Aditama

[11] Lestari, Beni, Suripto, dan Suharto. (2017). Penerapan Model Tari Bambu (Bamboo Dancing) dengan Media Kartu dalam Peningkatan Hasil Belajar Pendidikan Kewarganegaraan tentang Organisasi di Kelas V Sekolah Dasar. Kalam Cendekia PGSD Kebumen. 5(5), 447-452.

[12] Lestari, Ni Luh Adhe Yanti, I Gusti Agung Oka Negara dan Siti Zulaikha. (2014). Model Pembelajaran Kooperatif Tipe Jigsaw Berpengaruh terhadap Hasil Belajar IPA Siswa Kelas V SD Gugus I Kuta Badung. Jurnal Mimbar PGSD Universitas Pendidikan Ganesha.2(1), 1-10

[13] Masjid, A. (2014). Penilaian Autentik. Bandung: Remaja Rosdakarya.

[14] Mawardi. (2014). Pemberlakuan Kurikulum SD?MI Tahun 2013 dan Implikasinya. SCHOLARIA: Jurnal Pendidikan dan Kebudayaan. 4(3), 107-121.

[15] . (2018). Merancang Model dan Media Pembelajaran. SCHOLARIA: Jurnal Pendidikan dan Kebudayaan.8 (1), 26-40.

[16] Rini, Rismaerista \& Mawardi. (2015). Peningkatkan Keterampilan Proses Saintifik dan Hasil Belajar Siswa Kelas 4 SDN Slungkep 02 Tema Peduli Terhadap Makhluk Hidup Menggunakan Model Problem Based Learning. SCHOLARIA: Jurnal Pendidikan dan Kebudayaan. 5(1), 103-113.

[17] Shoimin, Aris. (2014). Model Pembelajaran Pendidikan dan Pengembangan. Jakarta: Prenada Media Group

[18] Sudijono, Anas. (2012). Pengantar Evaluasi Pendidikan. Jakarta: PT. RajaGrafindo Persada

[19] Sugiyanto. (2008). Model-model Pembelajaran Inovatif. Surakarta: PSG Rayon 13

[20] Suprijono, A. (2012). Cooperative Learning. Yogyakarta : Pustaka Pelajar.

[21] Trianto. (2012). Model-Model Pembelajaran Terpadu. Jakarta: Bumi Aksara.

[22] Wahyudi dan Kriswandani. (2010). Pengembangan Pembelajaran Matematika SD. Salatiga: ISBN.

[23] Zuraida. (2015). Pembelajaran Bamboo Dancing Salah Satu Model Cooperative Learning untuk Meningkatkan Proses Pembelajaran IPS di Sekolah Dasar. Jurnal Ilmiah Ilmu Pendidikan. 4(1), 120-127 